\title{
Czy można zaprojektować przyszłość? Polityczno-kulturowe korzenie dwudziestowiecznej transformacji Finlandii
}

\author{
Wojciech Woźniak \\ Uniwersytet Łódzki
}

DOI: http://dx.doi.org/10.18778/1733-8069.17.1.07

\begin{abstract}
Słowa kluczowe:
Finlandia,

transformacja,

modernizacja,

edukacja, tożsamość

narodowa, orientacja

na przyszłość
\end{abstract}

\begin{abstract}
Abstrakt: Artykuł podejmuje problematykę transformacji Finlandii w drugiej połowie $\mathrm{XX}$ wieku, której efektem jest osiągnięcie pozycji jednego z globalnych liderów w dziedzinie nowych technologii i rozwoju gospodarki opartej na wiedzy przy jednoczesnym znacznym podniesieniu jakości życia obywateli. Celem artykułu jest omówienie kombinacji wewnętrznych czynników związanych z działaniami fińskich elit, które umożliwiły tę transformację. Wykorzystując liczne źródła historyczne i odwołując się do koncepcji systemów-światów Wallersteina, artykuł koncentruje się w szczególności na specyfice XIX-wiecznego procesu narodowotwórczego, znaczeniu edukacji i systemu oświaty, orientacji na przyszłość oraz dominującego w społeczeństwie postrzegania nauki i wiedzy, jako kluczowych czynnikach definiujących proces modernizacji.
\end{abstract}

Wojciech Woźniak jest socjologiem. Jego zainteresowania naukowe dotyczą fińskiego modelu społeczno-gospodarczego oraz fińskich polityk publicznych, relacji między sportem a polityką, nierówności społecznych i dyskursu publicznego (szczególnie zjawiska paniki moralnej).

\section{Adres kontaktowy}

Katedra Socjologii Struktur i Zmian Społecznych

Wydział Ekonomiczno-Socjologiczny, Uniwersytet Łódzki

ul. Rewolucji 1905 r. nr 41/43, 90-214 Łódź

e-mail: wojciech.wozniak@uni.lodz.pl
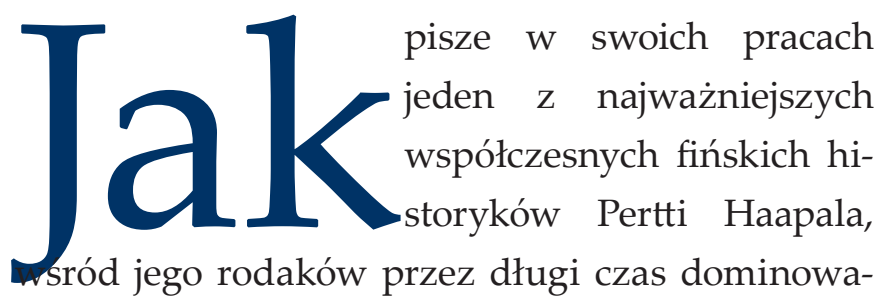
ło fatalistyczne przeświadczenie, że ich mentalne cechy na zawsze i na dobre determinują ich los. Cytowany przez niego fiński ekonomista w 1915 twierdził, że Finlandia nigdy nie stanie się społeczeństwem przemysłowym, bo Finom brakuje (mimo dominacji protestantyzmu) kapitalistycz- 
nego ducha. Finowie są powolni, leniwi i uparci, zamiast przyjmowania brytyjskiej zasady "czas to pieniądz”, wierzą, że „Bóg stworzył świat, ale w Biblii nie wspomina się, żeby się przy tym spieszył" (Haapala 2009: 10 [tłum. WW]). To ciekawa obserwacja, być może właśnie luterańska z ducha, przypisująca „winę" cechom własnym fińskiej populacji, a nie zewnętrznym warunkom życia, politycznym relacjom z potężnymi sąsiadami czy położeniu geograficznemu przekładającemu się na ograniczone zasoby naturalne czy klimat.

Tymczasem niespełna 100 lat później troje ekonomistów: Jari Ojala, Jari Eloranta i Jukka Jalava na okładce opasłego tomu zatytułowanego Droga do dobrobytu (2006) tak wprowadzają czytelników w historię gospodarczą Finlandii:

Fińska gospodarka to zwycięstwo nad przeciwnościami, historia sukcesu, która niewiele ma porównywalnych. Podczas okresu 1860-2000 produkt krajowy brutto wzrósł 21-krotnie, gdy inne kraje Unii Europejskiej w tym samym okresie osiągnęły wzrost 11-krotny. Dzisiaj Finlandia słynie ze swojej konkurencyjności, wysokich standardów edukacyjnych, minimalnej korupcji, umiejętności w tworzeniu i wykorzystywaniu najnowszych technologii oraz osiągających sukcesy przedsiębiorstw, z najważniejszym przykładem Nokii. [tłum. WW]

Abstrahując od - wyjątkowo jak na akademicką publikację-emocjonalno-entuzjastycznego tonu, trudno tej konstatacji odmówić trafności. Na przełomie XX i XXI wieku światowe media pisały o Finlandii jako o "cudownym dziecku nowych technologii", o „fińskim cudzie”, a o kolejnych bijących rekordy popularności modelach telefonów komórkowych Nokii jako o największym fińskim wynalazku od czasów sauny (Oinas 2005: 1229-1230; Knight, Ro- utti 2012: 77-78; Siilasma 2018: xii). Zaledwie kilka lat po głębokim kryzysie finansowo-gospodarczym lat 1991-1993, z towarzyszącą mu recesją oraz kilkunastoprocentowym, a lokalnie nawet ponad dwudziestoprocentowym bezrobociem, w rankingach Programu Narodów Zjednoczonych ds. Rozwoju, Banku Światowego i Światowego Forum Ekonomicznego Finlandia stała się światowym liderem w dziedzinie nowych technologii, konkurencyjności gospodarki i niskiego poziomu korupcji. Osiągnięto to przy zachowaniu typowej dla nordyckich państw opiekuńczych sieci bezpieczeństwa socjalnego oraz egalitarnych zasad redystrybucji dochodu narodowego. Nokia była światowym liderem w sprzedaży telefonów komórkowych, a w międzynarodowych badaniach uzyskiwała rozpoznawalność marki większą niż McDonald's, Toyota czy Disney (o historii firmy można przeczytać w: Oinas 2005: 12321233; Hira 2012, a o jej transformacji w globalny koncern i współczesnej sytuacji w Siilasma 2018).

Celem artykułu ${ }^{1}$ jest wskazanie $\mathrm{w}$ perspektywie długiego i średniego trwania czynników historyczno-kulturowych, które pozwoliły Finlandii przemieścić się $\mathrm{w}$ XX wieku z pozycji kraju peryferyjnego do globalnego gospodarczego rdzenia (w rozumieniu Wallersteinowskiej teorii systemów-światów, Wallerstein 2007). Niniejsze opracowanie zostało pomyślane jako esej socjologiczny, w którym omawiam i interpretuję historyczne procesy ostatnich dwóch stuleci, które umożliwiły tak zasadniczą transformację $\mathrm{w}$ tak krótkim czasie. Szczególną rolę przypisuję tu formacji narodowych elit politycznych, specyfice procesu narodowotwórczego, znaczeniu edukacji, wiedzy i nauki dla

\footnotetext{
${ }^{1}$ Wszystkie wątki zarysowane $\mathrm{w}$ tym artykule będą rozbudowane w monografii, która ukaże się w 2021 roku nakładem Wydawnictwa Uniwersytetu Łódzkiego. Za cenne uwagi, które pozwoliły poprawić artykuł, dziękuję recenzentom oraz Magdalenie Rek-Woźniak i Marcinowi Zarodowi.
} 
fińskich elit i społeczeństwa, a także dominującej wśród kluczowych aktorów realistycznej orientacji na przyszłość. Tylko biorąc te czynniki pod uwagę, można odpowiedzieć na pytanie zadane w tytule, czy, i pod jakimi warunkami, Finom udało się świadomie „zaprojektować przyszłość". Dodatkowym zadaniem tego opracowania jest uszczegółowienie i zniuansowanie obrazu fińskiego „modelu społeczno-gospodarczego" i jego źródeł, który w polskiej literaturze bywa prezentowany $\mathrm{w}$ sposób upraszczający lub ograniczający się do omówienia wąsko poszczególnych polityk sektorowych².

Ani ekonomiści, ani fińscy politycy nie twierdzą, że fińska droga do gospodarczego sukcesu w II połowie XX wielu była od początku strategicznie zaplanowana i zrealizowana. Wiele zmian, które pozwoliły Finlandii znaleźć się na przełomie bieżącego i minionego stulecia $\mathrm{w}$ rankingach najbardziej zaawansowanych i konkurencyjnych gospodarek świata, wynikało z czynników egzogennych. Niemniej w tym opracowaniu szczególną uwagę zwracam na procesy endogenne, które pozwoliły na wykorzystanie szansy stworzonej przez XX-wieczne zmiany geopolityczne $\mathrm{w}$ Europie oraz megatrendy związane z gospodarką światową. Niewiele krajów półperyferyjnych może doświadczyć zmiany statusu w którymś momencie swojej historii. Jak pokazuje Wallerstein (1976: 466), dla takiej transformacji kluczowa jest właśnie polityka wewnętrzna oraz planowanie gospodarcze, najczęściej dotyczą-

\footnotetext{
${ }^{2}$ W Polsce od czasu wydania Społeczeństwa informacyjnego i państwa dobrobytu Castellsa i Himanena w 2009 roku, 7 lat po światowej premierze, nie ukazało się żadne opracowanie koncentrujące się na Finlandii. W publikacjach nt. procesów modernizacyjnych $\mathrm{w}$ krajach skandynawskich traktowano Finlandię jako element klastra krajów nordyckich (np. Anioł 2013; Musiał 2013; Dziedziczak-Fołtyn, Musiał 2015). Szczegółowe omówienia polityk sektorowych ukazywały się zaś w zeszytach serii "Analizy Norden Centrum" publikowanych przez think tank Norden Centrum.
}

ce replikowania przez biedne kraje doświadczeń krajów zamożniejszych. Zmiany są więc wynikiem endogennych działań wynikających $\mathrm{z}$ obserwacji egzogennych czynników. Nie ma tu miejsca na szczegółową rekapitulację założeń teorii systemów-światów oraz sposobów jej empirycznego stosowania. W pracach tych temat Finlandii nie był zresztą szczególnie eksplorowany. Do 1918 roku trudno klasyfikować Finlandię w odniesieniu do modelu Wallersteinowskiego, nie była bowiem krajem suwerennym. Jednak, jak wskazuje Kiljunen (1992: 24), do zakończenia II wojny światowej struktura handlu, specjalizacja w eksporcie surowych (drewno) lub słabo przetworzonych produktów (pulpa papierowa i smoła), które odpowiadały za 90 procent fińskiego eksportu, lokowałyby Finlandię w grupie krajów peryferyjnych. Demokratyczne struktury państwowe oraz masowo dostępna edukacja z kolei były nietypowymi cechami dla krajów peryferyjnych, co pozwalałoby zapewne polemizować z takim przypisaniem. Sam Wallerstein w 1976 roku zaliczył Finlandię do grupy krajów półperyferyjnych (1976: 465). W późniejszych pracach badaczy empirycznie aplikujących teorię systemu-świata nie ma konsensusu dotyczącego momentu awansu do krajów centrum. Zdaniem jednych (Clark, Beckfield 2009) dokonał się on już w latach 80., podczas gdy inni naukowcy zaliczali Finlandię tego okresu wciąż do krajów półperyferyjnych (np. Arrighi, Drangel 1986).

Za końcową cezurę rozważań przyjąłem przełom XX i XXI wieku, gdy nie było wątpliwości, że Finlandia należy do krajów centrum. Symbolem trwałości nowych struktur i siły elastycznej adaptacji może być ponownie Nokia. Kryzys pierwszej dekady XXI wieku pozbawił ją pozycji lidera w produkcji telefonów komórkowych, nie odbierając jej jednak potencjału. W 2019 roku ponownie stała się 
kluczową globalną marką, będąc jedną z dwóch europejskich (obok szwedzkiego Ericssona) i trzech światowych (obok chińskiego Huaweia) korporacji dysponujących technologią niezbędną do tworzenia infrastruktury dla technologii mobilnej piątej generacji (5G).

Koncentruję się w tym artykule na trzech obszarach działalności państwa fińskiego: procesie narodowotwórczym w XIX wieku, państwowej edukacji oraz wykorzystaniu wiedzy naukowej w procesie podejmowania decyzji, jako tych, które miały zasadnicze znaczenie dla tworzenia zrębów przede wszystkim fińskiej polityki gospodarczej. Oddziaływały one jednak na wszystkie pozostałe polityki publiczne, tworzące system naczyń połączonych wpływających na wszystkie obszary życia społecznego (by przypomnieć szeroką definicję Thomasa R. Dye'a, wedle którego polityką publiczną jest wszystko, co rząd robi lub od robienia czego się świadomie powstrzymuje [zob. Dye 2013: 3]).

\section{Historia Finlandii. Kluczowe cezury}

Nie ma tu miejsca na choćby szkicowe omówienie dziejów Finlandii, warto jednak zaznaczyć istotne cezury oraz wydarzenia, których znajomość jest niezbędna do zrozumienia fenomenu fińskiej transformacji w XX wieku.

Do 1809 roku przez ponad sześć stuleci Półwysep Fiński stanowił integralną część Królestwa Szwecji. Następnie w wyniku skomplikowanej geopolitycznej układanki, której kulminacją była inwazja Rosji na Szwecję w 1808 roku, w wyniku traktatu pokojowego z Fredrikshamn, Finlandia została przyłączona do Imperium Rosyjskiego. Po raz pierwszy w historii stała się odrębnym, chociaż niesuwerennym, bytem politycznym jako Wielkie Księstwo Finlan- dii. Szwedzkie panowanie wywarło piętno na fińskiej kulturze, instytucjach politycznych, sposobach gospodarowania, szwedzki język stał się językiem tutejszych elit, a reformacja przyniosła dominującą do dziś religię luterańską. Jednak to stulecie, gdy terytorium fińskim rządził car Rosji jako Wielki Książe Finlandii, a administracyjne funkcje realizował rosyjski gubernator wraz z fińskim Senatem, przyniosło Finom poczucie odrębności, przebudzenie narodowe, powstanie społeczeństwa obywatelskiego, a wraz z upadkiem Imperium Carskiego, suwerenność i niepodległość (Lavery 2006 31-55; Meinander 2013: 55-75). Z polskiej perspektywy zaskakująco może brzmieć, że okres przynależności do carskiego imperium w fińskiej historiografii określa się często „wiekiem autonomii”, szczególnie dobrze wspominając okres panowania Aleksandra II, którego pomnik do dzisiaj stoi na Placu Senackim w centralnym punkcie Helsinek.

W 1917 w wyniku korzystnego zbiegu okoliczności Finlandia uzyskała niepodległość 3 . O wojnie domowej, która wybuchła w rok później, i jej konsekwencjach napiszę w dalszej części artykułu, warto jednak wspomnieć o kolejnym chronologicznie wydarzeniu, które wpłynęło na dwudziestowieczny los Finów. Po dwóch dekadach względnego spokoju i rozwoju, pod koniec 1939 roku fińska niepodległość została zagrożona zewnętrzną agresją. Ne-

\footnotetext{
${ }^{3}$ Postacią, która szczególnie przysłużyła się Finom w tym momencie historycznym, był Włodzimierz Iljicz Lenin, który $\mathrm{w}$ trakcie nielegalnej działalności w latach poprzedzających rewolucję 1917 roku wielokrotnie bywał w Finlandii. Notabene to w Tampere w 1905 roku spotkał po raz pierwszy Józefa Stalina. Po triumfie rewolucji, akurat w przypadku Finlandii, Lenin trzymał się sformułowanej w 1914 roku idei o prawie narodów do samostanowienia, licząc, że w wyniku korzystnego dla Kraju Rad przebiegu wojny domowej nowopowstałe państwo pozostanie w radzieckiej strefie wpływów. Stąd zupełnie inna w fińskiej historiografii i pamięci zbiorowej Finów recepcja postaci wodza rewolucji, którego pomniki można do dziś zobaczyć w niektórych fińskich miastach.
} 
gocjacje w sprawie pokojowego zaspokojenia żądań Związku Radzieckiego w kwestii przesunięcia granicy w okolicach Przesmyku Karelskiego skończyły się fiaskiem i wojska Armii Czerwonej rozpoczęły ofensywę. Wykorzystując swe nieliczne atuty taktyczne, mimo zdecydowanej przewagi wroga w ludziach i sprzęcie, Finowie powstrzymali jej marsz w głąb swojego terytorium. To wojna zimowa, kilka spektakularnych bitewnych zwycięstw i poważne straty poniesione przez ZSRR umiejscowiły dla globalnej opinii publicznej Finlandię na mapie świata, przyczyniając się także do budowy pierwszych pozytywnych skojarzeń. Toczona w ekstremalnych warunkach pogodowych przeciwko potężniejszemu agresorowi zimowa kampania pokazała światu wartość niepodległości dla mieszkańców małego kraju na północno-wschodniej rubieży Europy. Walka Finów była skuteczna, bo zapobiegła okupacji kraju, lecz okupiona stratami terytorialnymi, bo wschodnia Karelia znalazła się $\mathrm{w}$ granicach agresora. Sprzymierzenie się z Trzecią Rzeszą w celu odzyskania Karelii w wojnie kontynuacyjnej i ograniczony udział fińskich oddziałów w działaniach zbrojnych przeciwko ZSRR sprawiły jednak, że po II wojnie światowej Finlandia znalazła się w pokonanym obozie państw Osi (Hentila, Jussila, Nevakivi 2001; Kirby 2006). Jako jedyne z nich spłaciła całość kontrybucji wojennych. Ze względu na naciski Moskwy, jako jedyny kraj spoza bloku wschodniego, odmówiła przyjęcia wsparcia w ramach Planu Marshalla. Jak przyznają fińscy ekonomiści, fakt, że Związek Radziecki zażądał reparacji w sprzęcie pozwolił w krótkim czasie zintensyfikować produkcję przemysłową i przyspieszyć industrializację, szczególnie przed 1952 rokiem, gdy ostatni transport trafił za wschodnią granicę (Haarmann 2016: 142-143) ${ }^{4}$.

${ }^{4} 1952$ rok jest symboliczny dla Finów również w związku z faktem organizacji w Helsinkach drugich powojennych letnich igrzysk olimpijskich, które traktowano jako potwier-
W 1945 roku aż 70 procent populacji Finlandii mieszkało na terenach wiejskich, a ponad 60 procent było zatrudnione $\mathrm{w}$ rolnictwie i przemyśle leśnym. Procesy urbanizacji i migracja do miast w latach 60. spowodowały, że już w latach 70. te proporcje wyglądały inaczej (połowa społeczeństwa mieszkająca w miastach i jedna trzecia zatrudniona $\mathrm{w}$ rolnictwie i przemyśle), wciąż jednak odmiennie niż w większości zurbanizowanych i zindustrializowanych społeczeństw europejskich (Alapuro 1988; Simola 2005: 458). Na początku lat 50. liczba ludności Finlandii przekroczyła 4 miliony (od połowy XVIII do połowy XX wieku co pół wieku podwajała się liczba ludności [zob. Eloranta i in. 2006: 16; 20-23]).

Brak paliw kopalnych, minerałów, z wyjątkiem jednego znaczącego złoża miedzi odkrytego w 1906 roku w Outokumpu w Północnej Karelii (Hjerppe, Jalava 2006: 36), ograniczał możliwości zarabiania na eksploatacji surowców naturalnych. Jedynym dobrem, którego było zawsze pod dostatkiem, „zielonym złotem" Finlandii były lasy i pozyskiwane z nich drewno, najważniejszy zasób i towar eksportowy przez pół tysiąca lat. Produkcja drewna oraz przetwórstwo tego surowca (na smołę, węgiel drzewny i pulpę papierową) do lat 50 . XX wieku odpowiadała za prawie 90 procent fińskiego eksportu. Nigdzie na świecie dominacja monokultury przemysłu drzewnego nie była tak znacząca. Notabene tradycje przemysłu leśnego w paradoksalny sposób łączą się z myśleniem o przyszłości, szerzej o tym piszę w dalszej części artykułu.

dzenie międzynarodowego uznania i suwerennego statusu republiki. Ważnym procesem, który dotknął fińskie społeczeństwo w wyniku II wojny światowej, była również konieczność ewakuacji ponad 400 tysięcy obywateli (ok. 12\% ówczesnej populacji) z terenów Karelii utraconej na rzecz ZSRR i ich osiedlenia na terytorium Finlandii (Hjerppe, Jalava 2006: 46). 
Innym czynnikiem wpływającym na warunki i jakość życia mieszkańców było rolnictwo, którego rozwój był zdeterminowany przez klimat. Wiele upraw nie ma zastosowania w Finlandii ze względu na długie i mroźne zimy oraz okres wegetacyjny, który trwa nie więcej niż 180 dni (na południu kraju) i zaledwie 120 dni na północy (Ojala, Nummela 2006: 65-92). Finlandia wielokrotnie w dziejach doświadczała klęsk głodu. Ostatnia z nich, w latach 1866-1868, spowodowała śmierć prawie jednej dziesiątej populacji.

\section{Polityka i tożsamość narodowa - konsensus i elastyczna adaptacja}

Moment mobilizacji narodowej nadszedł w Finlandii później niż w innych krajach nordyckich, dopiero w XIX wieku pod carską władzą. Ówcześni liderzy polityczni postrzegali sytuację Wielkiego Księstwa Finlandii jako w ograniczonym stopniu suwerennego bytu politycznego w obrębie Rosyjskiego Imperium jako stałą. Fińska tożsamość narodowa nie powstawała zatem w kontrze wobec rosyjskiej dominacji, lecz zakładała lojalność wobec cara.

Kluczową rolę odgrywał ruch fennomański, którego liderem był Johan Vilhelm Snellman. Jego cel był praktyczny: upowszechnienie języka fińskiego w całym społeczeństwie poprzez szereg działań edukacyjnych, które kierowane były nie tylko do mas społecznych (o tym w podrozdziale o edukacji), ale również do najwyższych warstw społeczeństwa. Zdecydowana większość ówczesnego chłopskiego społeczeństwa posługiwała się językiem fińskim, ale językiem górnych segmentów struktury społecznej był szwedzki. Fennomani promowali fiński, by stał się również językiem akademickiej, politycznej i kulturalnej elity społeczeństwa. Dzięki lojalności wobec władz rosyjskich ten ambitny pro- gram udało się zrealizować, nie budząc antagonizmu Moskwy. Pod koniec XIX wieku fiński (mimo oficjalnej i do dzisiaj obowiązującej dwujęzyczności) stał się językiem aparatu państwowego i edukacji (Stenius 2012: 209-211). Drugą siłą polityczną kreującą klimat polityczno-kulturowy tego okresu byli liberałowie, którzy, nie kontestując konieczności zachowywania ugodowej postawy wobec Rosjan, próbowali powiązać fińskie elity z kulturą i stylem życia zachodnioeuropejskich społeczeństw, biorąc za wzór i punkt odniesienia przede wszystkim skandynawskich sąsiadów. Napięcia między fennomańskim nacjonalizmem i liberalną prozachodnią orientacją były stałym elementem dyskursu w XIX wieku. W okresie nasilonej presji rusyfikacyjnej pod koniec tego stulecia przerodził się w otwarty antagonizm, który jednak w długiej perspektywie zadziałał synergicznie, utrwalając narodową tożsamość i homogeniczność społeczeństwa fińskiego z jednej strony, z drugiej wzmacniając jego poczucie przynależności do świata zachodniego pod względem kulturowym i cywilizacyjnym. Kluczową rolę $\mathrm{w}$ tych debatach i ucieraniu się stanowisk odgrywała masowo czytana prasa. Jak pisze Stenius (2012: 214), wyedukowaną elitę zarażono nacjonalizmem, a naród wyedukowano, zmniejszając dystanse kulturowo-edukacyjne w społeczeństwie ${ }^{5}$. Nacjonalizm pozwolił na konsolidację kultury narodowej,

\footnotetext{
${ }^{5}$ Nie ma w tym artykule wystarczająco dużo miejsca, by przyjrzeć się bliżej mroczniejszym stronom przebudzenia narodowościowego w Finlandii oraz ekspansji edukacyjnej, w szczególności asymilacyjnej polityce prowadzonej w stosunku do zamieszkujących najodleglejszą północ Finlandii rdzennych ludów należących do grupy etnicznej Saamów. Ich populacja liczy dzisiaj ok. 10 tys. osób (w całej północnej Europie ok. 110 tysięcy). Prawa do pielęgnacji własnej kultury były przez cały XIX i XX wieku w znacznym stopniu ograniczone, dopiero w latach 90. ubiegłego stulecia uznano ich język za oficjalny język mniejszościowy i przyznano prawo do nauki finansowanej przez państwo po podpisaniu przez Finlandię „Europejskiej karty języków regionalnych lub mniejszościowych" (aktualne omówienie historycznych uwarunkowań polityk publicznych wobec Samów i ich współczesnych konsekwencji można znaleźć w: Kuhn 2020).
} 
a jednocześnie zaczął pełnić funkcję świeckiej religii wspierającej ruch emancypacji mas społecznych (Alapuro 1988: 92).

Finlandia była krajem wolnego chłopstwa, bez pańszczyzny i z rozbudowanym wiejskim systemem samorządności. Polityczną kulturę konsensusu i samorządności fińscy historycy wywodzą, podobnie jak $w$ przypadku innych państw skandynawskich, jeszcze z tradycji gromadzkich zebrań, które wybierały przedstawicieli lokalnych społeczności odpowiedzialnych za ich reprezentacje podczas negocjacji z władzami. W kraju bez pańszczyzny status tych wyborów był znaczący, podobnie jak obecnych $\mathrm{w}$ wielu lokalnych społecznościach stowarzyszeń. Nazywane przez Steniusa (2012: 213) przy wykorzystaniu współczesnej terminologii "organizacjami woluntarystycznymi", były emanacją oddolnego ruchu ludowego, brały współodpowiedzialność za rządzenie już od początku XIX wieku, współpracując z pochodzącymi z wyboru oficjalnymi przedstawicielstwami gromad (Lehtonen 1999).

Już w połowie XIX wieku najzamożniejsze warstwy wolnego chłopstwa były w podobnej sytuacji ekonomicznej co szwedzkojęzyczna szlachta, a ich polityczną pozycję poprawiła reforma z 1865 roku, która upodmiotowiła ich władztwo w sprawach lokalnych. Stan chłopski zrównano wówczas z innymi, a posiadający ziemię przedstawiciele chłopstwa zasiadali od tego roku w Senacie Wielkiego Księstwa Finlandii (Alapuro 1988: 36, 45).

Szczególnie z polskiej perspektywy zaskakująco może brzmieć opowieść o zakątku Imperium Rosyjskiego, w którym w XIX wieku następował rozkwit nierosyjskojęzycznej prasy, rozwijała się pluralistyczna scena polityczna i działały swobodnie setki organizacji i stowarzyszeń. Gdy w 1905 roku kozackie oddziały dławiły powstanie łódzkie, protesty fińskich robotników mające swoją kulminację podczas odczytania w Tampere „Czerwonej Deklaracji" (odezwy wzywającej stanowy senat do ustąpienia) przyniosły fińskiej prowincji poszerzenie autonomii (Haapala 2009). Dwa lata później powstała Eduskunta, jednoizbowy fiński parlament, a Finlandia stała się drugim na świecie krajem, w którym czynne i bierne prawo wyborcze przysługiwało wszystkim obywatelom bez względu na cenzus pochodzenia, wykształcenia czy też płeć.

Jak piszą fińscy historycy, największym paradoksem dziejów Finlandii jest wybuch i przebieg wojny domowej w roku 1918 (Haapala i in. 2010; Haapala 2014). Rok po uzyskaniu niepodległości po raz pierwszy $\mathrm{w}$ historii, $\mathrm{w}$ kraju całkowicie homogenicznym etnicznie i religijnie, o relatywnie płaskiej strukturze społecznej, bez silnej dominacji arystokracji i szlachty, bez zniewolonego chłopstwa, konflikt polityczny zaostrzył się na tyle, że doszło do eksplozji przemocy. Ponieważ na przełomie XIX i XX wieku rozwiązano fińskie formacje przynależące wcześniej do carskiej armii, w wojnie domowej stanęły naprzeciwko siebie oddziały niemające przeszkolenia ani doświadczeń w walce zbrojnej. Socjalistyczna „czerwona gwardia” formowana była przez działaczy Socjaldemokratycznej Partii Finlandii, a popierana przez bolszewicką Rosję, która jednak z różnych względów, przede wszystkim przez uwikłanie w wojnę z Niemcami, nie zapewniła im wystarczającego do zwycięstwa wsparcia militarnego ani sprzętowego. „Biały” obóz, konserwatywno-prawicowy, dążył do powołania monarchii zamiast demokratycznej republiki. Rządy Szwecji i Niemiec, obawiając się ekspansji idei rewolucyjnych na zachód Europy, wsparły 
go sprzętem i batalionem Jegrów, weteranów doświadczonych służbą na frontach I wojny światowej. Przechyliło to szalę zwycięstwa na rzecz dowodzonych przez dawnego carskiego oficera Generała Karla Gustawa Mannerheima „Białych” (Alapuro 1988; Haapala 2014). Wojna domowa przyniosła w kraju liczącym mniej niż 3 miliony mieszkańców aż 40 tysięcy zabitych. Trzy czwarte spośród nich to żołnierze Czerwonej Gwardii, spośród których zaledwie co czwarty zginął $\mathrm{w}$ walce. Pozostali to ofiary egzekucji, represji, a w szczególności niehumanitarnych warunków w obozach, w których zwycięzcy przetrzymywali jeńców. Rok po ustaniu bratobójczych walk, zaledwie miesiące po zwolnieniu więźniów z obozów, odbyły się w Finlandii demokratyczne wybory. Zwyciężyła pokonana w walce zbrojnej Socjaldemokratyczna Partia Finlandii, a partie polityczne związane z prawicą uznały ten wynik (Simola 2005: 457; Haapala $2009 ; 2014)^{6}$.

Właśnie wówczas rozpoczęła się przemiana fińskiej polityki. U progu suwerenności, doświadczona krwawą przemocą, przemieniła się w grę, w której nie tylko akceptuje, ale wręcz hołubi się negocjacyjne dochodzenie do konsensusu oraz instytucjonalno-prawne reguły rywalizacji politycznej. Konflikt między pracą a kapitałem stanowił podstawę rywalizacji politycznej, niemniej pamięć o hekatombie hamowała agresję i tłumiła radykalizmy. W kolejnych latach to konsensus polityczny stał się w fińskim dyskursie wartością autoteliczną, godną podkreślania i upamiętniania. Również dzisiejsze

\footnotetext{
${ }^{6}$ Ta masakra do dzisiaj stanowi zbiorową traumę w fińskiej świadomości narodowej, przez dekady była w tamtejszej polityce pamięci tematem tabu, przemilczanym epizodem wśród w większości heroicznych lub pozytywistycznych opowieści o Finlandii XX wieku. Dopiero w ostatnich dwóch dekadach, przy okazji 90. i 100. rocznicy wydarzeń z 1918 roku, zintensyfikowała się publiczna dyskusja, zainicjowana w znacznym stopniu debatą naukową (Haapala 2010).
}

narracje w polityce historycznej dotyczącej relacji przemysłowych traktują ponadklasowy konsensus robotników i kapitału jako szczególnie godny upamiętniania i pielęgnowania mit. Można by wręcz posłużyć się terminologią Hobsbawma o „wynalezionej tradycji” zgodnej kooperacji dla wspólnego celu i kompromisu klasowego zawartego być może z konieczności, lecz przestrzeganego przez zantagonizowanych aktorów (czyli związki zawodowe i organizacje pracodawców) pod rozjemczym, bacznym i sprawiedliwym nadzorem administracji państwa (Kettunen 2006: 295; Rek-Woźniak, Woźniak 2020). Hannu Simola (2017: 24-25) pisze, że wówczas narodziły się podstawy fenomenu, który określa wręcz "narodową mentalnością", łączącego fińskie elity polityczne oraz obywateli, a który do dziś wyróżnia fińskie społeczeństwo. Wysokiemu poziomowi zaufania uogólnionego (przeświadczenia, że ludziom generalnie można ufać) towarzyszy w Finlandii wysokie zaufanie do instytucji państwa (przeświadczenie, że instytucje działają dla dobra wspólnego). To drugie utrwaliło się dzięki doświadczaniu przez społeczeństwo pozytywnych skutków przeprowadzanych reform.

Finlandia później niż w przypadku innych krajów nordyckich rozpoczęła proces budowy państwa opiekuńczego ${ }^{7}$. Nowoczesne welfare state powstało w efekcie z jednej strony czynników zewnętrznych, o których poniżej, jak i politycznego planu sformułowanego mniej więcej na przełomie lat 50 . i 60. XX wieku, gdy Mauno Koivisto, gospodarczy ekspert Socjaldemokratycznej Partii Finlandii,

\footnotetext{
${ }_{7}$ Finlandia jako jedyny kraj nordycki po Wielkim Kryzysie nie wprowadziła w polityce gospodarczej rozwiązań kontrcyklicznych, które w innych krajach regionu uważa się za ważny etap budowy państwa dobrobytu już przed II wojną światową. Już wówczas w Szwecji, Danii i Norwegii stosunki pracy zaczęły być regulowane przez zbiorowe układy pracy, co w Finlandii nastąpiło dopiero pod koniec lat 60. (Kettunen 2001: 229-230).
} 
z grupą młodych naukowców oraz ekonomistów $\mathrm{z}$ banku centralnego powołali nieformalne ciało nazwane „Grupą O”. Jej członkowie w przyszłości stali się prominentnymi naukowcami, politykami, bankowcami, pełniąc istotne funkcje w fińskich instytucjach publicznych. Gdy socjaldemokraci przejęli stery władzy w 1966 roku (pozostając, z roczną przerwą, w koalicji rządowej przez kolejne ćwierć wieku), a Koivisto został Ministrem Finansów, plany zaczęły być wdrażane w życie. Fińscy badacze są zgodni, że zaprojektowanie i wdrożenie fińskiej odmiany socjaldemokratycznego modelu państwa dobrobytu byłoby utrudnione lub nastąpiło później, gdyby na początku lat 60. nie ukazała się praca Polityka społeczna dla lat 60., uznana później za najbardziej wpływową (w sensie zmiany, do której się przyczyniła) książkę z zakresu nauk społecznych opublikowaną kiedykolwiek w Finlandii. Napisana przez Pekkę Kuusiego (1961) stała się drogowskazem i poradnikiem, z którego kolejne rządy i parlamenty (w jednej kadencji wśród posłów był sam Kuusi) czerpały inspiracje i know-how (Kettunen 2001: 229-230) ${ }^{8}$. Nawet jeżeli plan autora nie został zrealizowany w pełni (w sensie koherentnego i całościowego wdrożenia wszystkich elementów), to był ważnym punktem odniesienia, szczególnie dla partii socjaldemokratycznej. Promowane przez Kuusiego przekonanie, wywiedzione z koncepcji kumulatywnej, okrężnej przyczynowości Gunnara Myrdala, że aktywna polityka społeczna, w tym transfery socjalne zwiększają szanse na rozwój gospodarczy stało się obowiązujące w fińskiej polityki społecznej.

${ }^{8}$ Co ciekawe, krewny autora, Eino Kuusi (1931) był autorem wpływowej książki o polityce społecznej opublikowanej na początku lat 30. Udowadniał w niej znaczenie naukowych diagnoz przy planowaniu spraw publicznych, w szczególności polityki gospodarczej. Politykę opartą na dowodach uznawał za fundament udanej realizacji jakichkolwiek mniej lub bardziej dalekosiężnych celów strategicznych w działaniach rządu.
Koivisto był politykiem, który dbał o konsensus wokół generalnego celu oraz najważniejszych środków do jego realizacji, pełniąc przez lata kluczowe funkcje polityczne zwieńczone w 1982 roku objęciem urzędu prezydenta republiki po 26-letnim okresie sprawowania władzy przez Urho Kekkonena (Immonen 1993: 171-172 za: Vivekandan 2012: 79). Liga Agrarna (przemianowana w 1963 roku na Partię Centrum) partia Kekkonena - najważniejszego polityka tej epoki - wspierała socjaldemokratów w większości reform wprowadzających podstawy państwa opiekuńczego, dbając w szczególny sposób o interesy swojego elektoratu (małych właścicieli, farmerów, pracowników rolnych). Kekkonen był aktywny we współtworzeniu wszystkich kolejnych rządów, jednak własną działalność koncentrował głównie w sferze polityki zagranicznej, przede wszystkim realizując doktrynę dyplomatycznej gry ze Związkiem Radzieckim, która miała gwarantować Finlandii niepodległość i suwerenność za cenę pewnych koncesji na rzecz sąsiedniego supermocarstwa (polityka zagraniczna wraz z polityką bezpieczeństwa do dzisiaj należą do prerogatyw prezydenckich $\mathrm{w}$ fińskim systemie politycznym, Kettunen 2001: 245).

Fiński „reżim polityki społecznej” został w najsłynniejszej typologii Gøsty Espinga-Andersena (1990) zaliczony do modelu socjaldemokratycznego, charakteryzującego się egalitaryzmem, niskim poziomem utowarowienia oraz uniwersalistyczną naturą większości świadczeń, czy to transferów pieniężnych, czy usług opiekuńczych, przyznawanych wszystkim obywatelom niezależnie od ich dochodów (Niemelä, Saarinen 2012).

Fińskie debaty publiczne są nastawione na poszukiwanie konsensusu $\mathrm{w}$ ramach akceptowalnych przez wszystkich aktorów negocjacji, a ich uczest- 
ników cechuje wstrzemięźliwość w formułowaniu ostrych, antagonizujących tez (Lounasmeri 2010: 69). Zdaniem Perttiego Alasuutariego (1996; Lounasmeri 2010: 72) dla wypracowania tej polityki niezbędne było wytworzenie $\mathrm{w}$ toku procesu historiozoficznego i ideotwórczego w latach wcześniejszych wspólnego dla wszystkich sił politycznych rozumienia statusu narodu fińskiego i fińskiej tożsamości ${ }^{9}$. Ważnym elementem tej wspólnoty przekonań było również postrzeganie gospodarki narodowej jako rodzaju korporacji, w której poszczególne podmioty (państwo, przedsiębiorcy i ich zrzeszenia, pracownicy i reprezentujące ich związki zawodowe) zobowiązane są do poszukiwania rozwiązań kompromisowych, których konsekwencje będą pozytywne dla bytu nadrzędnego (gospodarki narodowej właśnie), a akceptowalne dla wszystkich podmiotów.

Współczesną cechą charakterystyczną Finów jest chęć i umiejętność zrzeszania się $\mathrm{w}$ organizacje branżowe, związki zawodowe, stowarzyszenia oraz wysoki poziom ufności zarówno w sensowność działań kolektywnych, jak i wybranych oddolnie reprezentantów zbiorowości. W kraju o populacji niespełna pięciu i półmilionowej zarejestrowanych jest 130 tysięcy organizacji pozarządowych, czyli jedna na czterdziestu obywateli, statystyczny Fin jest członkiem trzech stowarzyszeń, a poziom uzwiązkowienia w całej gospodarce wynosi ok. 75 procent (Siitonen 2014: 72). Umiejętność kooperacji w formalnych stowarzyszeniach wywodzi się często od znaczenia, jakie w społeczeństwie zdominowanym przez wolne chłopstwo pełniły

\footnotetext{
${ }^{9}$ Jak wiadomo z prac m.in. Michela Foucaulta (2000) lub Ernesto Laclaua i Chantal Mouffe (1985), dążenie do konsensusu za wszelką ceną może mieć również negatywne konsekwencje, nie ma tu jednak miejsca, by je omawiać, te wątki znajdą się w monografii rozwijającej poruszane tu tematy.
}

przez stulecia samorządne gromadzkie reprezentacje lokalnych społeczności chłopskich. Traktowano je jako niezbędne w organizacji codziennego funkcjonowania struktur państwa podmioty. Niezależnie od tego, kto w Finlandii panował, przewodzili im etniczni Finowie.

Fiński nacjonalizm stawiał na piedestał dobrostan narodu związanego językiem, religią i miejscem, ale nie budował tożsamości na wrogości lub idiosynkrazji wobec innych krajów. Dominowało przeświadczenie, że naród fiński jest zbyt nieliczny i żyje w zbyt niekorzystnym geograficznie położeniu, by przetrwać samodzielnie, autarkia nie wchodziła w grę, bez poprawnych relacji z sąsiadami, eksportu surowców, a importu żywności i innych dóbr rzadkich nie da się gospodarować, rozwijać, poprawiać jakości życia mieszkańców. Kettunen (2014: 159) pisząc o okresie tworzenia się fińskiej tożsamości narodowej, odwołuje się do pism jednego z liderów ruchu fennomańskiego, Yrjö Koskinena (następcy Snellmana), który w latach 70. XIX wieku pisał, że samo semantyczne znaczenie fińskich terminów na określenie społeczeństwa (yhteiskunta) i państwa (valtio) implikuje normatywną deklarację rozwoju, który ma przynosić egalitarnie dystrybuowane korzyści: „,ich misją jest dbanie o wszelkie sfery wspólnego życia, pilnowanie, by egoistyczne interesy nie dominowały, gdyż to by doprowadziło do zagłady słabszych, a samo społeczeństwo do ruiny" (Koskinen 1874: 4 za: Kettunen 2014: 159 [tłum. WW]). Fińskie społeczeństwo w myśli nacjonalistycznych ideologów miało być świadome swoich niedostatków, samokrytyczne i zdolne do antycypacji przyszłości, przyjmujące prospektywną orientację uczenia się od bardziej rozwiniętych krajów, centrów modernizacji. Miało być jednocześnie przedmiotem i podmiotem zmian, którymi miała sterować wiedza i polityka. 


\section{Edukacja: równość i zaufanie}

W 2000 roku przeprowadzono pierwsze w historii międzynarodowe badanie porównawcze PISA (Programme for International Student Assessment) sfinansowane przez Organizację Współpracy Gospodarczej i Rozwoju. Był to jeden z największych w historii projektów porównawczych, obejmował przeprowadzone w 32 krajach badanie 15-letnich uczniów, którzy rozwiązywali zadania i testy $\mathrm{w}$ trzech obszarach: czytanie i interpretacja (reading literacy), matematyka (mathematical literacy) i rozumowanie w naukach przyrodniczych (science literacy). Badanie miało nie tyle mierzyć poziom wiedzy uczniów w poszczególnych krajach $\mathrm{w}$ odniesieniu do lokalnych programów nauczania, ale raczej sprawdzać przygotowanie nastolatków do rozwiązywania zadań iproblemów bardziej praktycznych, powiązanych z tematyką trzech wyodrębnionych dziedzin. Gdy wyniki zostały ogłoszone, okazało się, że Finlandia jest bezapelacyjnym liderem wśród krajów europejskich, utrzymując tę pozycję w kolejnych edycjach.

W mass mediach całego świata pojawiło się określenie "fiński cud edukacyjny", w kolejnych latach skwapliwie wykorzystane przez Finów, którzy z systemu edukacji stworzyli kolejny element budowania marki swojego kraju, a oświatowe know-how stało się kolejnym dobrem eksportowym i narzędziem soft power $\mathrm{w}$ relacjach dyplomatycznych (Simola 2005; Wojciuk, Michałek, Stormowska 2015). Odwołanie do cudu miało opisywać niezwykłość sytuacji, w której bardzo dobrym wynikom we wszystkich testowanych obszarach towarzyszy niewielkie ich zróżnicowanie pomiędzy szkołami oraz znacznie niższy niż w innych krajach statystyczny wpływ rodziny pochodzenia (zarówno pod względem zamożności, jak i wykształcenia rodziców) na wyniki testów. Stało to w opozycji do dominujących przeświadczeń o tym, że dla efektywności kształcenia ważna jest rywalizacja między szkołami, a istnienie szkół dla elity podnosi średni poziom jakości systemu edukacji.

Konstrukcja fińskiego systemu edukacyjnego, która umożliwiła ten międzynarodowy sukces, jest dobrze znana i opisana (np. Woźniak 2008; Sahlberg 2015; Lonka 2018). Próbując wytłumaczyć złożoność procesów, które do niego doprowadziły trzeba jednak sięgnąć daleko w przeszłość. Finowie byli, jak już wspomniano, rolniczym ludem, rządzonym przez nieliczną, identyfikującą się z fińską tożsamością, ale posługującą językiem królestwa Szwecji elitą. Do połowy XVI wieku fiński był chłopskim językiem mówionym. Pierwsza wersja fińskiego alfabetu „w piśmie” powstała dopiero w 1543 dzięki Mikaelowi Agricoli, duchownemu i późniejszemu biskupowi Turku. Pięć lat później Agricola przetłumaczył na fiński Biblię, co wiązało się z wymaganiami religii protestanckiej przyjętej $\mathrm{w}$ królestwie Szwecji przez Gustawa I Wazę. Postulowana przez luterańskie normy umiejętność czytania Biblii we własnym języku stała się podstawą akcji edukacyjnej prowadzonej na terenie Finlandii przez tamtejsze parafie, przy których zaczęły powstawać pierwsze szkoły powszechne. Sytuacja nie zmieniła się, gdy w 1809 roku Finlandia stała się częścią Imperium Rosyjskiego, które nie ingerowało w kwestie religijne. Od XVIII wieku w luterańskich szkołach parafialnych istniały dostępne dla wszystkich biblioteki, a pod koniec kolejnego stulecia na rzadko zaludnionym terytorium Finlandii funkcjonowało już około 2000 bibliotek publicznych, powstałych głównie dzięki Towarzystwu na rzecz Edukacji Powszechnej, oraz kolejne kilkaset prowadzonych przez różne organizacje młodzieżowe. Już pod koniec XVIII wieku - jak szacuje się na podstawie 
źródeł parafialnych - połowa ludności Finlandii umiała czytać, a gdy w 1892 roku język fiński uzyskał równy szwedzkiemu status prawny, analfabetyzm dotyczył zaledwie 3 procent posługującej się nim populacji (Hietala 2001: 11-12; Lonka 2018: 23-24) $)^{10}$. W latach 60. XIX wieku dzięki pastorowi Udo Cygneaeusowi, wspieranemu przez Snellmana, głównego ideologa fennomańskiego przebudzenia narodowego, powstał w Finlandii system szkół podstawowych dostępnych dla wszystkich, niezależnie od płci i pochodzenia społecznego. W tej samej dekadzie rozpoczęto na wielką skalę kształcenie nauczycieli, by zaspokoić rosnące w całym kraju zapotrzebowanie na ich pracę (Lonka 2018: 26-27).

Wysiłek skierowany na alfabetyzację populacji wynikał nie tylko z pobudek religijnych, ale również z zarysowanych czynników nacjonalistycznych. Budowanie tożsamości narodowej odbywało się w Finlandii poprzez promowanie kształcenia i czytelnictwa oraz organizowanie masowego dostępu do szkół i bibliotek. Zdobywanie wiedzy stało się warunkiem indywidualnego rozwoju dającego szansę na awans społeczny jednostek, jak i budowę wspólnoty opartej o wspólną religię i język oraz dającej uniwersalne poczucie przynależności do narodu poprzez relatywnie do innych krajów europejskich niewielkie dystynkcje klasowe.

Haapala za kluczową "przewagę konkurencyjną", która pozwoliła zacofanej Finlandii stopniowo odrabiać dystans do innych krajów europejskich, uznaje całkowite umasowienie szkolnictwa u progu

\footnotetext{
${ }^{10}$ Finlandia do dzisiaj pozostała krajem dwujęzycznym, lecz kwestia języka szwedzkiego jako języka urzędowego i związanych z tym formalnych wymogów nie stała się nigdy istotnym tematem sporów lub politycznych debat. Nawet tuż po zdobyciu niepodległości i konstruowaniu zrębów fińskiej państwowości przez znaczących polityków uznawana była za „,sześciorzędną" wobec innych wyzwań (Saukkonen 2012: 5-6).
}

XX wieku, dodając, że wykorzystano potencjał całego społeczeństwa, gdyż obowiązek szkolny obejmował również fińskie dziewczęta, których odsetek w szkołach ponadpodstawowych był w 1910 największy na świecie (Haapala 2009: 10). W XX wieku to wykształcone kobiety, pracujące jako urzędniczki, działaczki społeczne i polityczne czy przede wszystkim w sektorze edukacyjnym, przyczyniły się do wzmocnienia ludzkiego potencjału, a ponadto okazały się ważnymi aktorkami zmiany społecznej we wszystkich obszarach rzeczywistości (Ojala, Karonen 2006).

Egalitaryzm dotyczący płci, ale i pochodzenia społeczno-klasowego jest ważną cechą fińskiego ustroju, deklarowaną do dzisiaj jako jedna z wartości, na której zbudowano republikę, szczególnie jednak zauważalną $\mathrm{w}$ odniesieniu do systemu oświaty i kwestii edukacyjnej. W trakcie licznych wizyt studyjnych w fińskich edukacyjnych placówkach, które odbyłem w ostatnich 7 latach (w przedszkolach, podstawówkach, szkołach średnich wszystkich typów, na kilku uczelniach i w placówkach kształcenia ustawicznego dorosłych), wszyscy nauczyciele, wykładowcy lub dyrektorzy szkół opowiadający o fińskiej oświacie czuli się zobowiązani do podkreślenia, że zbudowano ją przede wszystkim na fundamencie równości. Egalitarny dostęp do kształcenia podkreślano częściej niż efektywność edukacyjną, jakość mierzoną wynikami testów, zaawansowanie technologiczne infrastruktury szkolnej lub profesjonalizm i formalne wykształcenie kadry. W praktyce wynika z tego wyłączenie systemu edukacyjnego spod wolnorynkowej konkurencji. Opiera się na założeniu, że rynkowa gra nie sprawdza się, gdy trzeba stworzyć system edukacyjny, który ma działać dla dobra wszystkich warstw społecznych. Stąd w Finlandii (poza nielicznymi placówkami religijnymi) brak szkolnictwa prywatnego, 
a żadne instytucje edukacyjne nie mogą działać na zasadach komercyjnych.

Drugim czynnikiem istotnym dla stabilności systemu jest podzielane zarówno przez fińskich obywateli, jak i decydentów przeświadczenie, że edukacja jest priorytetowym zadaniem państwa, wokół którego warto budować - trwający już wiele lat - polityczny konsensus. Obecny kształt systemu oświaty, z 9-letnią obowiązkową i jednolitą szkołą podstawową, którego konstrukcji przypisuje się znaczną część odpowiedzialności za fiński sukces edukacyjny, został skonstruowany w latach 60 ., a wprowadzony w życie w roku 1970. Poprzedziły go analizy wyników badań w zakresie pedagogiki, socjologii edukacji oraz psychologii rozwojowej i psychologii uczenia się (Lavonen 2017: 2). Poza politycznymi planistami i ekspertami kluczową rolę w jego opracowaniu odegrali sami nauczyciele, $\mathrm{z}$ jednej strony wykorzystując własne doświadczenia, z drugiej wywierając presję poprzez organizacje związkowe na wzmocnienie pozycji i autonomii nauczycieli w systemie szkolnym, ale również na podniesienie ich wynagrodzeń. Większość elementów fińskiego system szkolnego jest dobrze opisana we wzmiankowanych wcześniej publikacjach, ale warto wspomnieć, że wprawdzie kształt ram państwowej edukacji opracowany jest na poziomie ogólnokrajowym, a zasady wynikają z rozstrzygnięć ustrojowych, jednak w oświacie panuje daleko posunięta decentralizacja i samorządność. Lokalne władze, odpowiedzialne za organizację edukacji i pilnowanie standardów, są zobowiązane współpracować z kierownictwem szkól, nauczycielami oraz rodzicami, opracowując programy nauczania odpowiadające lokalnie zdiagnozowanym potrzebom oraz dostosowywane do możliwości uczniów. Szkoły podstawowe i średnie, które miałem okazję odwiedzić w lapońskim Ivalo, położonym około 300 kilo- metrów na północ od koła podbiegunowego, oferowały szereg treści powiązanych ściśle z historią i kulturą tego regionu, na przykład naukę języka Saamów lub regionalnego, wywodzącego się z tradycji tego ludu, rzemiosła. Ponieważ wszystkim uczniom państwo gwarantuje darmowy transport do szkoły, w liczącym około 4 tys. mieszkańców Ivalo spostrzec można liczne podwożące uczniów pod szkołę taksówki. Władze szkoły wyjaśniły, że dzieci trzeba przywieźć z rozproszonych w promieniu kilkudziesięciu kilometrów małych wsi i osad. Objazd autokaru byłby zbyt kosztowny, skorzystanie z lokalnej firmy taksówkarskiej jest dla władz municypalnych finansowo efektywniejszym narzędziem realizacji ustawowego prawa do bezpłatnej podróży do szkoły dla wszystkich uczniów. Z kolei w większych ośrodkach miejskich oferta edukacyjna dostosowywana jest do możliwości i potrzeb tamtejszych uczniów i rodziców. W szkołach o znacznym odsetku dzieci imigrantów uwzględnia się zatem ich specyficzne potrzeby, które w wielu innych placówkach w ogóle nie występują (Lavonen 2017: 2-5).

Kolejną istotną cechą fińskiego szkolnictwa, o której niewiele mówi się $\mathrm{w}$ popularnych opracowaniach na jego temat, jest przeświadczenie o szkodliwości prowadzenia rankingów szkół opartych o wąsko rozumianą efektywność kształcenia. Brzmi to paradoksalnie w kontekście fińskich sukcesów w badaniach PISA i wykorzystywania ich do promowania kraju. W Finlandii jednak nie prowadzi się takich zestawień, nie publikuje również danych porównawczych, w publicznej oświacie rywalizacja między szkołami o uczniów nie jest traktowana jako zaleta zwiększająca efektywność systemu. Nie oznacza to, że nie ma w nim miejsca na jakąkolwiek rywalizację. Ta dotyczy przede wszystkim dostępu do zawodu nauczycielskiego. Instytucjonalne wzmocnienie pozycji nauczyciela uważa się za jeden z czynników 
fińskiego sukcesu edukacyjnego. Fińscy decydenci uznali, że „uwolnienie rynku” w systemie szkolnictwa wyższego byłoby niekorzystne, stąd uczelnie co roku oferują ograniczoną liczbę miejsc na studiach przygotowujących do podjęcia pracy nauczycielskiej, która jest skorelowana z wyliczanym na podstawie danych demograficznych zapotrzebowaniem na ich usługi w przyszłości. $W$ efekcie posada nauczyciela gwarantuje stabilność zatrudnienia, a wynagradzana jest na poziomie zbliżonym do zarobków wysokiej klasy specjalistów w sektorze prywatnym. W konsekwencji studia nauczycielskie należą do najbardziej obleganych w Finlandii. Innym niezbędnym elementem systemu jest wzajemne zaufanie między nauczycielami, kierownictwem szkół, zarządzającymi nimi jednostkami samorządu a decydentami szczebla centralnego, wynikające z przeświadczenia, że każda z tych grup stara się w zgodny ze swoją ekspercką wiedzą działać dla dobra. W efekcie, jak pisze Lavonen (2017: 6), od początku lat 90. nie ma w Finlandii zorganizowanego centralnego systemu ewaluacji pracy nauczycieli, ani powszechnego systemu testowania wyników nauczania. Instytucje lokalnie odpowiedzialne za szkoły nadzorują realizację zlecanych szkołom zadań w odniesieniu do lokalnych potrzeb, zaś ocena pracy nauczyciela opiera się o hospitacje prowadzone przez innych nauczycieli.

Niektórzy fińscy akademicy, jak Hannu Simola, profesor socjologii edukacji, nie negując wymienionych instytucjonalnych uwarunkowań, które były niezbędne do zorganizowania systemu oświatowego w tak efektywny sposób, piszą wprost o kolektywnej, autorytarnej i skłonnej do podporządkowywania się autorytetom mentalności zbiorowej Finów. Tendencja do akceptacji autorytetu dotyczy zarówno zachowania uczniów w systemie szkolnym, jak i większości obywateli, którzy wierzą i akceptują, że decydenci wiedzą, jak zorganizować system, by działał (Simola 2005: 457-459). Simola nie stroni również od wyjaśnień klasowych. Jak pisze, nauczyciele toczyli przez dziesięciolecia „średnioklasowe wojny na dwóch frontach". Z jednej strony, starając się przekonywać robotnicze i chłopskie masy, że edukacja ich dzieci przyniesie korzyści, i że ich potomstwo zostanie w odpowiedni sposób „zaopiekowane” w szkołach. Z drugiej strony musieli nieustannie przekonywać establishment polityczny o zasadności masowego i powszechnego kształcenia oraz o swojej w tym procesie roli (Simola 2005: 460).

\section{Przyszłość: wiedza i samodzielność}

Fińscy badacze wskazują również, że - zapewne przynajmniej częściowo dzięki reformacji - idee europejskiego oświecenia przyjęły się najpierw wśród fińskich elit, a następnie wśród społeczeństwa, przynajmniej w kwestii organizacji życia gospodarczego:

Wartości oświeceniowe oznaczały z jednej strony akceptację przeświadczenia, że to nauka i technologia, „wiedza użyteczna” były kluczowe dla długofalowego rozwoju gospodarczego, z drugiej strony gotowość do powściągnięcia się od pogoni za krótkoterminowym zyskiem, oparcie się o konkurencyjny rynek, otwarty dla każdego, mobilność i sensownie ograniczony wpływ rządu. (Mokyr 2006: 11 [tłum. WW])

Symbolicznym potwierdzeniem dominacji myślenia długofalowego może być fakt, że po setkach lat nieustannej eksploatacji w 2020 roku Finlandia wciąż jest najbardziej lesistym krajem Europy. Lasy pokrywają ponad $70 \%$ powierzchni kraju. Być może stało się tak również dlatego, że duchowi przywódcy podkreślając symboliczne znaczenie lasu, formuło- 
wali też brzmiące nawet $\mathrm{z}$ dzisiejszej perspektywy zasadnie i aktualnie stricte ekologiczne postulaty dbałości i odpowiedzialności za najważniejszy zasób kraju. Zacharias Topelius w wydanym w 1875 dziele Boken om vårt land [Księga naszych ziem, najlepiej znana pod fińskim tytułem Maamme kirja] pisał:

Las jest bezcenny, jest bezcenny, bo bez niego ta ziemia nie nadawałaby się do zamieszkiwania przez ludzi. (...) Powinno się o tym pamiętać bardziej, niż się pamięta. Żaden kraj nie zależy od lasów tak jak Finlandia, a jednak żadna nacja nie traktuje lasu tak źle jak Finowie. Każdego roku poszerzają się wypalone obszary lasów liściastych, w zamian sadzi się nieliczne lasy iglaste. (...) W ten sposób niszczy się fiński bezcenny las. Żądza zysku zaćmiewa wielu, którzy wycinają całe połacie swoich lasów, zamiast ograniczyć się do starszych drzew i mieć stałą zrównoważoną korzyść ze swojej własności. W ten sposób dzieciom zostawią ubogą, zniszczoną ziemię. (2018: 257-258 [tłum. WW])

O zarówno symbolicznym, jak i praktycznym znaczeniu lasów dla Finów można się przekonać w niezwykłym Muzeum Lasu Lusto w miejscowości Punkaharju. Narracja koncentruje się wokół symbiozy natury, kultury i nauki związanej z lasem, który zapewnia kolejnym pokoleniom Finów byt i schronienie. W opowieści tej jest miejsce na przedchrześcijańską animistyczną mitologię na czele ze „złotym królem lasu”, czyli niedźwiedziem, totemicznym symbolem Finlandii (Pentikäinen 2007: 1), jak i na prezentację supernowoczesnych harwesterów do pozyskiwania drewna, których Finlandia jest jednym z dwóch największych producentów na świecie.

Maamme kirja dla kolejnych pokoleń Finów stała się kluczowym podręcznikiem historii i geografii, a jej znaczenie dla wzmacniania fińskiej tożsamości narodowej można porównać tylko z narodowym eposem, Kalevalą. Topelius był ważną postacią ruchu narodowego przebudzenia, poetą i pisarzem, ale także akademikiem, rektorem helsińskiego uniwersytetu, którego profesorami byli również Elias Lönnrot odpowiedzialny za opracowanie i opublikowanie Kalevali na podstawie swych etnograficznych badań oraz lider ruchu fennomańskiego Johan Vilhelm Snellman. W przypadku Finlandii to nie arystokraci, wojskowi, politycy czy duchowni, ale akademicy budowali i pielęgnowali zręby tożsamości narodowej, zarówno piórem, jak i swoją twórczością naukową. Snellman, poza działalnością ideologiczną, interesował się i kształcił w zakresie polityki gospodarczej, rolnictwa, finansów państwa oraz infrastruktury kolejowej. Gdy objął funkcję szefa fińskiego banku centralnego, to jego zasługą, w momencie powstania fińskiej waluty (markki), było powiązanie jej wartości z ceną kruszcu (srebra), a nie wartością rosyjskiego rubla, co pozwoliło po latach łatwiej uniezależnić się od rosyjskiej gospodarki.

Idee narodowe łączyły się z działaniami pozytywistycznymi, a naukę i rozwój gospodarki traktowano jako patriotyczne działania na rzecz państwa. Ta historycznie uwarunkowana wiara w wiedzę naukową jako niezbędny element modernizacji okazała się fundamentem, na którym w XX wieku można było budować nową rzeczywistość społeczno-gospodarczą Finlandii. W latach 50. i 60. badania nad przyszłością zaczęły zdobywać popularność, a laboratoria zajmujące się foresight-em i futurologią zaczęły powstawać w wielu placówkach i laboratoriach badawczych świata, szczególnie mocno rozwijając się w Japonii i Stanach Zjednoczonych, a na Starym Kontynencie w Niemczech, Wielkiej Brytanii i Szwecji (Tapio, Sirkka 2018: 111-112). 
Kolejne dekady przyniosły rozwój i instytucjonalizację zorganizowanej naukowo refleksji na temat wyzwań przyszłości. Warto się przyjrzeć, w jaki sposób instytucjonalizowano i wykorzystywano synergię wiary w sens finansowania badań naukowych, kapitalistycznej konkurencyjności, politycznego konsensusu i wysokiego zaufania społecznego, by pod nadzorem państwa stworzyć sieć publicznych instytucji, które umożliwiły opuszczenie peryferii. Ważnym aktorem była tu wspomniana już nieformalna, ale wpływowa Grupa O, integrująca ekspertów i decydentów planujących modernizację kraju, ale pierwszą instytucją, którą wykorzystano w tym celu, było VTT (Valtion teknillinen tutkimuslaitos), czyli Narodowego Centrum Badawcze, które powstało już w 1942 roku w celu eksperckiego wzmocnienia przemysłu zbrojeniowego. Większość analityków uznaje, że kluczowe znaczenie dla innowacyjności fińskiej gospodarki miała powołana w 1967 roku, a ufundowana przez fiński Bank Centralny z okazji 50-lecia uzyskania niepodległości Sitra (Narodowy Fundusz Badań i Rozwoju). Instytucja ta łączy funkcje niezależnego think tanku doradzającego rządowi oraz publicznego inwestora wybierającego do dofinansowania nowe przedsięwzięcia, głównie prace badawczo-rozwojowe (także nowopowstające firmy na zasadzie venture capital) pod warunkiem, że są one wysoko innowacyjne i działają w jednym z obszarów zdefiniowanych przez państwo jako ważne dla przyszłego rozwoju. Były to zadania związane zarówno z nowymi technologiami (np. konstrukcja pierwszej międzyuczelnianej sieci komputerowej), jak na przykład z ekologią i rozwojem zrównoważonym, ale również $\mathrm{z}$ badaniami mającymi na celu poprawę jakości życia obywateli: funkcjonowania instytucji, służby zdrowia, planowania miejskiego.

Seminaria organizowane przez Sitra Information Society Strategy and Program Formulation dotyczyły głownie zarządzania polityką gospodarczą oraz stymulowania prac rozwojowo-badawczych w poszczególnych sektorach rynku nowych technologii i pozwoliły najważniejszym decydentom oraz aktorom $\mathrm{z}$ różnych instytucji sektora publicznego i prywatnego uzyskać know how niezbędne do projektowania i wdrażania planów strategicznych (Knight, Routti 2012: 78, 99). W dużej mierze dzięki Sitrze i wynikom badań prowadzonych przez nią powstał w 1983 roku Tekes (Fundusz na Rzecz Technologii i Innowacji, w 2018 po połączeniu z rządową agencją promocji międzynarodowej Finpro Oy przemianowany na Business Finland). Tekes przejął większość zadań związanych z finansowaniem innowacyjnych badań aplikacyjnych prowadzonych przez instytucje państwowe (uczelnie, instytuty badawcze). Trzy z czterech największych programów badawczych dotyczyły nowych technologii, w szczególności telekomunikacyjnych, i miały zasadnicze znaczenie dla późniejszego sukcesu kraju jako lidera światowego w tej dziedzinie (Castells, Himanen 2009: 68-109)11. Jak pokazuje Hira (2012), jednym z głównych beneficjentów tych programów wsparcia była mało znana wówczas poza Finlandią firma o nazwie Nokia.

Fińscy ekonomiści nie mają wątpliwości, że najważniejszy czynnik wzrostu produktywności gospodarki, a w szczególności jej innowacyjności, wiązał się $z$, publicznym planowaniem i efektywnie działającymi instytucjami państwa (Asplund, Maliranta 2006: 267-270; Knight, Routti 2012: 82). Ich rola nie byłaby tak znacząca, gdyby nie dysponowały zna-

\footnotetext{
${ }^{11}$ Większość programów grantowych finansowanych przez Tekes wymaga partnerstwa instytucji publicznych z firmami prywatnymi. Akademicki urbanista, z którym przeprowadzono wywiad ekspercki, opowiadał, że czasem jest to biurokratyczny wymóg, który realizowany jest wyłącznie pro forma, wykorzystując osobiste kontakty i angażując znajomych przedsiębiorców. Głównym fundatorem badań podstawowych jest stricte akademicka instytucja o nazwie Academy of Finland.
} 
czącymi środkami. Dzięki ponadpartyjnemu konsensusowi finansowanie badań i rozwoju w drugiej połowie XX wieku w Finlandii rosło nieustannie, osiągając u progu XXI wieku poziom 3,5 procent PKB, jeden z najwyższych na świecie. O znaczeniu nauki może świadczyć również najwyższy wśród krajów OECD odsetek badaczy w relacji do liczebności populacji (Knight, Routti 2012: 78).

W celu wzmocnienia politycznego zaplecza dla procesów modernizacyjnych powołano w 1992 roku Komitet na Rzecz Przyszłości, będący wówczas jedynym takim ciałem na świecie. Jest to jedna z szesnastu stałych komisji w fińskim sejmie, składająca się z 17 parlamentarzystów wybieranych proporcjonalnie do siły mandatów poszczególnych partii. O ile pozostałe Komisje powiązane są z poszczególnymi ministerstwami, to Komitet na Rzecz Przyszłości podlega bezpośrednio premierowi. Jego zadaniem jest prowadzenie dialogu pomiędzy partiami na temat wyzwań, jakie stają przed Finlandią w perspektywie dłuższej niż czteroletnia kadencja. Przynajmniej raz w czasie kadencji rząd zobowiązany jest zaprezentować strategiczny dokument dotyczący przyszłości, monitorujący zmiany od czasu publikacji poprzedniego oraz aktualizujący strategię. Komisja ma za zadanie śledzić rozwój nauki, w szczególności weryfikować trafność badań typu foresight, zamawiać ekspertyzy naukowe, komentować działania innych komisji i ministerstw (w zakresie ich wpływu na długoterminowe plany strategiczne). Zaakceptowane przez Komisję, a opracowane na podstawie naukowych ekspertyz wskazówki są ważnym elementem planowania polityki naukowo-badawczej (Tiihonen 2014; Höyssä 2017). Komisja współpracuje z naukowcami z całej Finlandii, zatrudniając $\mathrm{w}$ razie potrzeby ekspertów z zagranicy, oraz z fińskimi agencjami ds. innowacji i nowych technologii. Stałym partnerem Komi- sji w zakresie badań typu foresight jest zaś powstałe również w 1992 roku na Uniwersytecie w Turku Finland Futures Research Centre (Tapio, Heinonen 2018). Licząca w momencie powstania trzech badaczy instytucja dzisiaj zatrudnia ich na stałe pięćdziesięcioro i ma na koncie setki projektów oraz ponad tysiąc publikacji. Specjalizuje się dzisiaj również w kształceniu ekspertów w dziedzinie future studies, na takim kierunku można zdobyć dyplom magistra i stopień doktora.

Proces instytucjonalizacji systemu podejmowania strategicznych decyzji i prowadzenia polityki innowacji, inwestycyjnej i gospodarczej sugeruje, że fińska polityka publiczna wykazywała się znaczną elastycznością i umiejętnością adaptacji do zmieniających się wyzwań. Powstawanie kolejnych instytucji publicznych układa się w kontinuum powiązane ściśle $\mathrm{z}$ globalnymi zmianami gospodarczymi i technologicznymi. W apogeum głębokiego wewnętrznego kryzysu gospodarczego i 3-letniej recesji lat 1991-1993 powołano do życia stricte polityczną, ale pluralistyczną komisję parlamentarną. Jej celem było - we współpracy z rządem - zapewnianie politycznego wsparcia oraz pilnowanie kierun$\mathrm{ku}$ strategicznych zmian i inwestycji. Utrzymanie kursu wymagało politycznego parasola ze względu na rosnące doraźne potrzeby, wynikające właśnie z kryzysu, które mogłyby być zarzewiem politycznych sporów między poszczególnymi resortami i grupami interesu.

Sposób, w jaki fińska gospodarka powróciła na ścieżkę wzrostu gospodarczego po kryzysie początku lat 90., w opinii ekspertów, ale także obywateli potwierdził obraną wcześniej ścieżkę strategicznej transformacji państwa. Przekształcenie kryzysu w szansę wzmocniło przeświadczenie, że inwestycje $\mathrm{w}$ inwestycje $\mathrm{w}$ infrastrukturę oraz badania 
i rozwój są dalece niewystarczające bez utrzymywania stabilnego finansowania systemu edukacji. Bez wykwalifikowanej kadry, kompetentnych i nowocześnie myślących przedsiębiorców oraz wykształconych administratorów stabilny rozwój gospodarczy okazał się niemożliwy (Knight, Routti 2012: 100). Ponadto pojawiły się kolejne empiryczne dowody, że dostępność sieci bezpieczeństwa socjalnego, typowa dla krajów nordyckich o socjaldemokratycznym reżimie polityki społecznej, jest czynnikiem zwiększającym, a nie zmniejszającym skłonność do ryzyka i podejmowania decyzji w sytuacji, gdy podejmujący je (przede wszystkim młodzi ludzie operujący w sektorze startupów branży ICT) mają gwarancję, że nietrafione pomysły nie przyczynią się do radykalnego pogorszenia się ich sytuacji majątkowej oraz statusu społecznego. Podkreślić można, że intencjonalnie zaplanowany system inwestycji pozwolił fińskiej wersji „,kapitalizmu koordynowanego" odnieść sukces, który nie ograniczył się tylko do przyspieszenia i zwielokrotnienia produktu krajowego, ale pozwolił - dzięki redystrybucyjnym pryncypiom modelu socjaldemokratycznego - na powszechne korzystanie $\mathrm{z}$ tego sukcesu większości społeczeństwa (Oinas 2005: 1234-1238). W efekcie wzmocniło się również w samych Finach przeświadczenie, że ramy dla tworzenia innowacyjnej infrastruktury muszą być zapewnione przez instytucje państwa. A ponieważ jakość ich usług i eksperckość kadry ma zasadnicze znaczenie, nie powinno się na nich oszczędzać.

\section{Podsumowanie}

Pertti Haapala (2009: 15 [tłum. WW]) cytuje bazujący na stereotypach żart, że Finowie tak długo siedzieli w swoich lasach, że jak już z nich wyszli, to ciekawiło ich wszystko, co nowe i inne, by podsumować swoje rozważania już na poważniejszą nutę:
Wszystko jest kwestią adaptacji: jak dostosować się do środowiska (naturalnego i społecznego), jak przetrwać przy sąsiadach, jak korzystać na relacjach z innymi, jak chronić swoje interesy i kulturę itp. Być może niespodziewanie okazało się, że fińskie społeczeństwo okazało się być elastycznym, otwartym na zmiany i nowe idee, chociaż w polityce elastyczność często postrzega się jako oportunizm. W komunikacji z innymi i gospodarce Finlandia okazała się społeczeństwem otwartym, bo była za mała, by przetrwać w samotności. Była zależna gospodarczo od innych, ale to ona przeważnie korzystała na wymianach z nimi.

Haapala (2009: 10) uznaje, że przytoczony na początku artykułu dominujący na początku XIX wieku fatalistyczny brak wiary w gospodarczy rozwój Finlandii, przeświadczenie, że „karty zostały już rozdane" było zrozumiałe, gdy około 100 lat temu porównywano sytuację Finlandii z uprzemysłowionymi już krajami takimi jak Wielka Brytania, Szwecja, Niemcy. Jednak XX wiek przyniósł Finom redefinicję ich autopercepcji, a światu nowy wizerunek małego kraju i nielicznego narodu, któremu udało się - patrząc z perspektywy długiego trwania - w zasadzie znienacka i bez zapowiedzi dołączyć do grona rozwiniętych gospodarczo państw, z najbardziej zaawansowaną technologią i najwyższą jakością życia mieszkańców.

Wallerstein, pisząc o zmianach pozwalających przezwyciężać kryzysy i ograniczenia poprzez radykalną zmianę systemu, opisuje sytuację bifurkacji, sytuacji „rozwidlenia ścieżki” umożliwiającej wybór dalszej drogi, gdy wielość drobnych decyzji może wpłynąć na decyzję, a wiele drobnych zmian może przynieść zasadniczą modyfikację całego systemu (2007: 134, 149). Podsumowując, warto wyodrębnić kilka czynników endogenicznych, których syner- 
giczna konfiguracja przyczyniła się do opisanej zmiany pozycji Finlandii. Większość z nich wiązała się ściśle z procesem kształtowania się elit narodowych, które okazały się zdolne do podjęcia próby sterowania zmianami, jakie wymuszały strukturalne megatrendy.

Z jednej strony odrębność i homogeniczność kulturowa, językowa, etniczna i religijna ułatwiały dbanie o własną, spójną tożsamość. Z drugiej powszechna była świadomość płynąca z historycznego doświadczenia, że Finlandia nie jest i nie będzie nigdy samotną i samowystarczalną wyspą, która uświadamiała tak rządzącym, jak i rządzonym, że muszą z otoczeniem się komunikować, handlować, współdziałać, negocjować. W globalizującym się i komplikującym pod każdym względem świecie te relacje musiały się nasilać, a kraj musiał się dostosowywać do warunków zewnętrznych.

Kettunen, podsumowując polityczne debaty o przyszłości i kierunkach rozwoju państwa trwające w Finlandii w ostatnich dwóch stuleciach, wskazuje, że przy świadomości peryferyjnej pozycji kraju fińskie elity polityczne nie przestawały analitycznie obserwować rzeczywistości poza granicami. Próbowano czerpać wzorce modernizacji z sukcesów innych i unikać powtarzania błędów, mając świadomość, że pewne zjawiska są nieuchronne, lecz pojawią się w późno się uprzemysławiającym i urbanizującym kraju ze znacznym opóźnieniem (Kettunen 2006: 294). Porównania międzynarodowe stawały się podstawą realistycznej kalkulacji, opartych na naukowych diagnozach polityk publicznych, które jednocześnie „ucierały się" w długich negocjacjach, by stać się elementem ponadpartyjnego konsensusu.

$\mathrm{W}$ wielu miejscach na świecie, $\mathrm{w}$ mniej lub bardziej zmitologizowanej formie, to odwołania do świetla- nej przeszłości wyznaczają horyzont oczekiwań. Fińscy politycy, niezależnie od ideowych afiliacji, nie mieli żadnej historycznej „złotej epoki”, do której mogliby się odwoływać, nie istniało narodowe imaginarium "starych, dobrych czasów”. Wygląda na to, że to ostatnie dekady mogą stać się takim punktem odniesienia $\mathrm{w}$ przyszłości ${ }^{12}$. Warto w tym miejscu poświęcić kilka słów zagadnieniu czasu społecznego i próbie interpretacji przemian orientacji temporalnej dominującej w Finlandii. Jak w każdym społeczeństwie agrarnym, przez większość historii dominował czas cykliczny, regulowany zmianami pór roku i rytmem przyrody, determinujący całość wyobrażeń temporalnych na temat rzeczywistości (Tarkowska 1987: 146). W okresie przebudzenia narodowego w XIX wieku, jak wskazałem za pracami Kettunena, fińskie elity narodowe formułowały $\mathrm{w}$ ideowych deklaracjach postulaty podkreślające niezbędność orientacji na przyszłość, konieczność podejmowania prób jej świadomego projektowania, opartego o wiedzę, naukę, racjonalne planowanie i realistyczną ocenę własnych słabości i szans. Przez kolejne dekady te postulaty nie mogły zostać zrealizowane, brak szans i możli-

\footnotetext{
${ }^{12}$ Naukowe i racjonalne sterowanie procesami gospodarczymi i społecznymi, dyskurs innowacyjności stał się kluczową narracją o Finlandii i Finach schyłku XX i XXI wieku, spychając w cień zarówno wiele utartych stereotypów, jak i dotychczasowych dumnie hołubionych pozytywnych cech zbiorowych, jak choćby słynne sisu. Ten endemiczny i nie całkiem przetłumaczalny termin oznaczał determinację, stoickie znoszenie niedogodności, hart ducha i zimny upór w realizacji celów i przekuwanie niepowodzeń w szansy. Rozpoznawalność międzynarodową zyskał w 1940 roku, gdy na czołówki mediów światowych trafiły relacje z frontu Wojny Zimowej. Stał się elementem budowania wizerunku kraju, tak na zewnątrz, jak i dla przyjeżdżających do Finlandii turystów, dla których wykazanie się sisu przybierało najczęściej formę kąpieli w przeręblu po saunie lub wychylenia kieliszka wódki z salmiakki. Dzisiaj jest stałym elementem memów internetowych o Finlandii, gdzie pojawia się obok fińskich hokeistów, bezpiecznych i wydajnych szkół czy Nokii 3310 - do dzisiaj symbolu niezniszczalnej elektroniki użytkowej (,gdy czujesz się bezużyteczny, pomyśl, że ktoś kiedyś wymyślił etui ochronne dla Nokii 3310" - głosi jeden z memów, dostępny np. tu: https://9gag.com/gag/apQZQqb).
} 
wości działania był zdeterminowany brakiem suwerenności, naturalną orientacją był prezentyzm, rozumiany jako trwanie z krótką perspektywą czasową ograniczoną warunkami zewnętrznymi. Ten typ orientacji (być może z przerwą na dwie dekady niepodległości w okresie międzywojennym) dominował do upadku żelaznej kurtyny. Finlandyzacja okresu zimnej wojny oznaczała bowiem brak pełnej suwerenności w decydowaniu o polityce wewnętrznej i zewnętrznej. Od zakończenia zimnej wojny dominuje orientacja łącząca prezentyzm z orientacją przyszłościową przy odrzuceniu przeszłości. Przeszłość traktowana jest tu jak lustro, przypominające o pozytywnie waloryzowanych chłopskich i robotniczych korzeniach, ale przede wszystkim czasach niedostatku, do których nie wolno ponownie dopuścić, z kolej bieg czasu współczesnego i postrzeganie przyszłości są linearne i towarzyszy im poczucie sprawczości. Jak pisała o takiej orientacji Elżbieta Tarkowska (1987: 146):

Orientację tę charakteryzuje poczucie czasu ciągłego, tyle że czas ten ma pewien określony początek, ulokowany w teraźniejszości. Teraźniejszość jest punktem oparcia dla kształtowania przyszłości. Orientacja ta właściwa jest ideologiom postępu, rozumianego jako

\section{Bibliografia}

Alapuro Risto (1988) State and revolution in Finland. Berkeley: University of California Press.

Alasuutari Pertti (1996) Toinen tasavalta. Suomi 1946-1994. Tampere: Vastapaino.

Ali-Yrkkö Jyrki i in. (2017) Riding the wave: Finland in the changing tides of globalisation. Helsinki: Elinkeinoelämän Tutkimuslaitos, ETLA. proces ciągły, jednorodny, nieodwracalny. Dobrze wyraża ją hasło „,zas pracuje dla nas".

Pierwsze lata po II wojnie światowej nazywane są przez fińskich ekonomistów „wielkim doganianiem" (the great catch-up). Pozwoliły przesunąć się Finlandii do grona krajów półperyferyjnych (Ali-Yrkkö i in. 2017: 41). Pod koniec XX wieku publiczna i bezpłatna edukacja wysokiej jakości oraz inwestycje $\mathrm{w}$ naukę i badania okazały się wehikułem indywidualnego awansu, mobilności społecznej dla jednostek pochodzących ze wszystkich klas społecznych, pozwalając również całemu społeczeństwu i gospodarce awansować awansować do centrum systemu-świata, stać się miejscem, które dyktuje standardy, następnie powielane i kopiowane w mniej rozwiniętych gospodarczo i zaawansowanych technologicznie krajach. Zmiany te nie byłyby możliwe bez specyficznego zestawu procesów i czynników, które ukształtowały fińską elitę oraz zaprojektowany przez nią instytucjonalny system polityk publicznych. Tylko biorąc pod uwagę całą ich konfigurację można zrozumieć XX-wieczną transformację Finlandii i jej pozycji w globalnym systemie i odpowiedzieć na tytułowe pytanie: „czasem się uda".
Anioł Włodzimierz (2013) Szlak Norden. Modernizacja po skandynawsku. Warszawa: DW Elipsa.

Arrighi Giovanni, Drangel Jessica (1986) Stratification of the World-Economy: An Exploration of the Semiperipheral Zone. „Review X", vol. 1, s. 9-74.

Asplund Rita, Maliranta Mika (2006) Productivity growth: The Role of Human Capital and Technology [w:] Jari Ojala, Jari Elo- 
ranta, Jukka Jalava, eds., Road to Prosperity: An Economic History of Finland. Helsinki: Suomalaisen kirjallisuuden seura, s. 263-284.

Castells Manuel, Himanen Pekka (2009) Społeczeństwo informacyjne i państwo dobrobytu. Przełożyli Michał Penkala, Michał Sutowski. Warszawa: Wydawnictwo Krytyki Politycznej.

Clark Rob, Beckfield Jason (2009) A new trichotomous measure of world-system position using the international trade network. "International Journal of Comparative Sociology", vol. 50, s. 5-38.

Clements Jonathan (2010) Mannerheim. Prezydent, żotnierz, szpieg. Przełożyli Dagny Kurdwanowska, Piotr Gebethner. Poznań: Wydawnictwo Replika.

Dye Thomas R. (2013) Understanding Public Policy. London: Pearson.

Dziedziczak-Foltyn Agnieszka, Musiał Kazimierz (2015) Dyskursy modernizacyjne i wielkie narracje rozwoju. Polska a kraje nordyckie. „Przegląd Socjologiczny”, t. 2, s. 9-43.

Eloranta Jari i in. (2006) On the road to prosperity: an introduction. In The road to prosperity: an economic history of Finland [w:] Jari Ojala, Jari Eloranta, Jukka Jalava, eds., Road to Prosperity: An Economic History of Finland. Helsinki: Suomalaisen kirjallisuuden seura, s. 15-32.

Esping-Andersen Gøsta (1990) The three worlds of welfare capitalism. Princeton, NJ: Princeton.

Forsberg Tuomas, Pesu Matti (2016) The "Finlandisation" of Finland: The Ideal Type, the Historical Model, and the Lessons Learnt. „Diplomacy \& Statecraft”, vol. 27, s. 473-495.

Foucault Michel (2000) Power. Essential Works of Foucault 19541984. Volume Three. New York: The New Press.

Haapala Pertti (2009) Modernization of Finland 1800-2000 [w:] Mikko Perkiö, ed., Perspectives to Global Social Development. Tampere: Tampere University Press, s. 48-66.

Haapala Pertti (2010) The Many Truths of 1918 [w:] Pertti Haapala i in., eds., Tampere 1918. Town in the Civil War. Tampere: Tampere Museums' Publications, s. 185-197.

Haapala Pertti (2014) The Expected and Non-expected Roots of Chaos: Preconditions of the Finnish Civil War [w:] Tuomas Tepora, Aapo Roselius, eds., The Finnish Civil War 2018. Leiden, Boston: Brill, s. 21-50.
Haapala Pertti i in., eds. (2010) Tampere. A Town in the Civil War. Tampere: Vapriikki.

Haarmann Harald (2016) Modern Finland. Jefferson: McFarland.

Hentila Seppo, Jussila Osmo, Nevakivi Jukka (2001) Historia polityczna Finlandii 1809-1999. Przełożyła Bożena Kojro. Kraków: Universitas.

Hietala Marjatta (2001) Foundation of Libraries in the Historical Context [w:] Ilkka Mäkinen, red., Finnish Public Libraries in the 20th Century. Tampere: Tampere University Press, s. 7-22.

Hira Anil (2012): Secrets behind the Finnish miracle: the rise of Nokia. "International Journal of Technology and Globalisation”, vol. 6, s. 38-64.

Hjerppe Riitta, Jalava Jukka (2006) Economic Growth and Structural Change - A Century and a Half of Catching-up [w:] Jari Ojala, Jari Eloranta, Jukka Jalava, eds., Road to Prosperity: An Economic History of Finland. Helsinki: Suomalaisen kirjallisuuden seura, s. 33-64.

Höyssä Maria (2017) Committee for the Future Parliament of Finland [dostęp 10 lipca 2020 r.]. Dostępny w Internecie: 〈https://cor. europa.eu/Documents/Migrated/events/2017_Tulevaisuusvaliokunta_esitys_ENGLANTI\%20180123.pdf >.

Kettunen Pauli (2001) The Nordic Welfare State in Finland, "Scandinavian Journal of History", vol. 26(3), s. 225-247.

Kettunen Pauli (2006) The Tension between the Social and the Economic - A Historical Perspective on a Welfare State [w:] Jari Ojala, Jari Eloranta, Jukka Jalava, eds., Road to Prosperity: An Economic History of Finland. Helsinki: Suomalaisen kirjallisuuden seura, s. $285-313$.

Kettunen Pauli (2014) Language of Social Politics in Finland [w:] Daniel Béland, Klaus Petersen, eds., Analysing Social Policy Concepts and Language: Comparative and Transnational Perspectives. Bristol: Policy Press, s. 157-176.

Kettunen Pauli (2019) The Conceptual History of the Welfare State in Finland [w:] Nils Edling, ed., Changing Meanings of the Welfare State: Histories of a Key Concept in the Nordic Countries. Berghahn Books, Oxford \& New York, s. 225-275.

Kiljunen Kimmo (1992) Finland and the International Division of Labour. London: Palgrave Macmillan.

Kirby David (2006) A Concise History of Finland. Cambridge: Cambridge University Press. 
Knight Peter T., Routti Jorma (2012) Information Society and Consensus Formation in Finland [w:] Hanna Nagy K., Peter T. Knight, eds., National Strategies to Harness Information Technology. New York: Springer, s. 77-106.

Kuhn Gabriel (2020) Liberating Sápmi: Indigenous Resistance in Europe's Far North. Oakland: PM Press.

Kuusi Eino (1931) Sosialipolitiikka. Porvoo: WSOY.

Kuusi Pekka (1961) 60-luvun sosiaalipolitiikka. Porvoo: WSOY.

Laclau Ernesto, Chantal Mouffe (1985) Hegemony and Socialist Strategy: Towards a Radical Democratic Politics. London: Verso.

Lavery Jason E. (2006) The history of Finland. Westport: Greenwood Press.

Lavonen Jari (2017) Governance decentralisation in education: Finnish innovation in education. "Revista de Educación a Distancia”, Núm. 53, s. 1-2.

Lehtonen Tuomas M. S. (1999) Europe's Northern Frontier, Perspectives on Finland's Western Identity. Jyväskylä: Sitra.

Lonka Kirsti (2018) Phenomenal Learning From Finland. Helsinki: Edita Publishing.

Lounasmeri Lotta (2010) Visions of Finland in the Age of Globalization. „Nordicom Review”, vol. 31, s. 69-85.

Meinander Henrik (2013) History of Finland. Oxford: Oxford University Press.

Mokyr Joel (2006) Successful Small Open Economies and the Importance of Good Institutions [w:] Jari Ojala, Jari Eloranta, Jukka Jalava, eds., Road to Prosperity: An Economic History of Finland. Helsinki: Suomalaisen kirjallisuuden seura, s. 8-14.

Musiał Kazimierz (2013) Uniwersytet na miare swego czasu. Transformacja społeczna $w$ dobie post-industrialnej a zmiany $w$ szkolnictwie wyższym krajów nordyckich. Gdańsk: słowo/obraz terytoria.

Niemelä, Mikko, Saarinen Arttu (2012) The role of ideas and institutional change in Finnish public sector reform. "Policy \& Politics", vol. 40, s. 171-191.

Oinas Päivi (2005) Finland: A success story? „European Planning Studies", vol. 13, no. 8, s. 1227-1244.

Ojala Jari, Karonen Petri (2006) Business: Rooted in Social Capital over the Centuries [w:] Jari Ojala, Jari Eloranta, Jukka Jalava, eds., Road to Prosperity: An Economic History of Finland. Helsinki: Suomalaisen kirjallisuuden seura, s. 93-126.

Ojala Jari, Nummela Ilkka (2006) Feeding Economic Growth: Agriculture [w:] Jari Ojala, Jari Eloranta, Jukka Jalava, eds., Road to Prosperity: An Economic History of Finland. Helsinki: Suomalaisen kirjallisuuden seura, s. 65-92.

Ojala Jari, Eloranta Jari, Jalava Jukka, eds. (2006) Road to Prosperity: An Economic History of Finland. Helsinki: Suomalaisen kirjallisuuden seura.

Pentikäinen Juha (2007) Golden King of the Forest - The Lore of the Northern Bear. Helsinki: Etnika OY.

Sahlberg Pasi (2015) Finnish Lessons 2.0: What Can the World Learn from Educational Change in Finland? Second Edition. New York: Teachers College Press.

Rek-Woźniak Magdalena, Woźniak Wojciech (2020) Working-class and Memory Policy in Post-Industrial Cities. Łódź, Poland, and Tampere, Finland, Compared. „International Labor and Working Class History", no 98, s. 5-21 [dostęp 10 lipca 2020 r.]. Dostępny w Internecie: ‘https://tinyurl.com/y58h77xc〉.

Saukkonen Pasi (2012) The Finnish Paradox: Language and Politics in Finland. RECODE. Working Paper Series. Online Working Paper No. 05.

Siilasmaa Risto (2018) Transforming NOKIA: The Power of Paranoid Optimism to Lead Through Colossal Change. New York: McGraw-Hill Education.

Siitonen Lauri (2014) Non-Governmental Organizations and Finland's Development Policy [w:] Paul Hoebink, Lau Schulpen, eds., Private Development Aid in Europe. EADI Global Development Series. London: Palgrave Macmillan, s. 71-107.

Simola Hannu (2005) The Finnish miracle of PISA: historical and sociological remarks on teaching and teacher education. "Comparative Education", vol. 41, s. 455-470.

Simola Hannu i in. (2017) Dynamics in Education Politics: Understanding and explaining the Finnish case. Abingdon, New York: Routledge.

Stenius Henrik (2012) Paradoxes of the Finnish Political Culture [w:] Jóhann Páll Árnason, Björn Wittrock, eds., Nordic paths to modernity. New York: Berghahn Books, s. 207-228.

Tapio Petri, Sirkka Heinonen (2018) Focused Futures from Finland. „World Futures Review”, vol. 10, s. 111-135. 
Tarkowska Elżbieta (1987) Czas w społeczeństwie. Problemy, tradycje, kierunki badań. Wrocław: Zakład Narodowy im. Ossolińskich. Wydawnictwo Polskiej Akademii Nauk.

Tiihonen Paula (2014) What's Committee for the Future? [dostęp 10 lipca 2020 r.]. Dostępny w Internecie: https://www.eduskunta.fi/ FI/naineduskuntatoimii/julkaisut/Documents/tuvj_10+2014.pdf».

Topelius Zacharias (2018) Maamme kirja. Digitaalinen editio. Helsinki: Suomalaisen Kirjallisuuden Seura ja Svenska litteratursällskapet i Finland [dostęp 10 lipca 2020 r.]. Dostępny w Internecie: http://maammekirja.fi/index.php.

Vivekanandan B. (2012) The Finnish Welfare State in the 1990s: Challenges and Responses. „International Studies”, vol. 49, s. 77-112.
Wallerstein Immanuel (1976) Semi-Peripheral Countries and the Contemporary World Crisis. "Theory and Society", vol. 3, 4, s. $461-483$.

Wallerstein Immanuel (2007) Analiza systemów-światów. Wprowadzenie. Przełożyli Katarzyna Gawlicz, Marcin Starnawski. Warszawa: Wydawnictwo Akademickie Dialog.

Wojciuk Anna, Michałek Maciej, Stormowska Marta (2015) Education as a source and tool of soft power in international relations. „European Political Science”, vol. 14, s. 298-317.

Woźniak Wojciech (2008) System edukacyjny jako instrument wyrównania szans. Przypadek Finlandii. „Polityka społeczna”, numer specjalny Dziedziczenie nierówności społecznych, s. 36-38.

\title{
Cytowanie
}

Woźniak Wojciech (2021) Czy można zaprojektować przyszłość? Polityczno-kulturowe korzenie dwudziestowiecznej transformacji Finlandii. „Przegląd Socjologii Jakościowej”, t. 17, nr 1, s. 90-112 [dostęp dzień, miesiąc, rok]. Dostępny w Internecie: «www.przegladsocjologiijakosciowej.org). DOI: http://dx.doi.org/10.18778/1733-8069.17.1.07

\section{Can One Design the Future? On the Political and Cultural Roots of the Transformation of Finland in the Twenty-First Century}

\begin{abstract}
The article undertakes the topic of the unprecedented transformation of Finland in the second half of the 20th century, which resulted in the country's achieving the leading global position in technological development and the creation of knowledge-based society while simultaneously significantly improving the citizens' well-being and quality of life. The article aims to describe the combination of internal factors connected with the actions of the Finnish elites which had facilitated this transformation. It utilizes numerous historical sources and applies Immanuel Wallerstein's concept of world-systems, concentrating in particular on the specificity of the 19th-century nation-building process, the significance of the education and school system, the prospective orientation, and the socially dominant way of perceiving science and knowledge as crucial factors defining the modernization process.
\end{abstract}

Keywords: Finland, transformation, modernization, education, national identity, prospective orientation 